\title{
Behavioural and socially parasitic relations between Polyergus rufescens (Latr.) and Formica polyctena Först. (Hymenoptera: Formicidae)
}

\author{
Wojciech Czechowski
}

Czechowski, W. 2007: Behavioural and socially parasitic relations between Polyergus rufescens (Latr.) and Formica polyctena Först. (Hymenoptera: Formicidae). - Entomol. Fennica 18: 54-64.

Polyergus rufescens (Latr.), an obligate slave-maker, and Formica polyctena Först., an aggressive, territorial wood ant species, rarely co-occur in the field, and there are almost no data on their mutual relations under natural conditions. These interactions were studied in the Białowieża Forest (NE Poland), based on two $P$. rufescens colonies (with Formica fusca L. slaves) nesting within the territories of $F$. polyctena. The wood ants routinely searched the immediate vicinity of $P$. rufescens nests, whereas $P$. rufescens ants raided $F$. fusca colonies very close to $F$. polyctena nests or their columns passed right next to them, they eventually crossed wood ants' foraging and removal routes, and even directly attacked $F$. polyctena colonies and robbed their brood. Interspecific relations in these particular situations are described and discussed in the contexts of supposed chemical camouflage/mimicry of $P$. rufescens and interspecific competition hierarchy in ants.

W. Czechowski, Museum and Institute of Zoology PAS, Laboratory of Social and Myrmecophilous Insects, Wilcza St 64, PL-00-679 Warszawa, Poland; E-mail: wcz@miiz.waw.pl

Received 19 May 2006, accepted 11 December 2006

\section{Introduction}

Formica sanguinea Latr., the European bloodred ant, and Polyergus rufescens (Latr.), the European Amazon ant, are Palaearctic, facultative and obligate respectively, slave-making social parasites of Serviformica For. ant species. F. sanguinea, a common polytope of dry habitats (including forests), frequently co-occurs with wood ants (Formica s. str.) and, unavoidably, often comes into direct contact with them; it is even able to use wood ants as (atypical) slave species. There is abundant literature regarding these interactions, both with regard to social parasitism (for reviews see Czechowski 1996, 2003b) and behavioural ecology (e.g. Punttila et al. 1996, Czechowski 2000, Czechowski \& Vepsäläinen 2001, Czechowski \& Markó 2006). P. rufescens is a rare oligotope of dry grasslands, and therefore it has little chance of encounters with wood ants in the field. No wonder that reports on relations between $P$. rufescens and wood ants under natural conditions are scarce. Thus Forel (1900) described a queenright (polygynous) colony of $F$. pratensis Retz. (otherwise a polytope of dry habitats) mixed with $P$. rufescens and $F$. (Serviformica) fusca L. workers. As for behavioural data, Dobrzański \& Dobrzańska (1978) and 
Dobrzańska \& Dobrzański (1989) mentioned a $P$. rufescens colony that was gradually destroyed as a result of heavy losses when its raids crossed a route of nearby F. rufa L. More recently, Czechowski (2006) reported that a $F$. polyctena Först. route was a factor indirectly promoting supposed emancipation of $F$. fusca slaves from colonies of $P$. rufescens. Mabelis (2000) noticed that $P$. rufescens (with $F$. fusca slaves) did not react aggressively towards $F$. rufa workers in the vicinity of its own nest, and concluded that the latter might also be enslaved. Deconinck et al. (2001) subsequently announced that conclusion as a fact, most probably too rashly. Then, as so far there has been no reliable confirmation of $P$. rufescens using Formica s. str. workers as atypical slaves. However, on the analogy of $F$. sangui$n e a$, another slave-maker, this possibility can not be ruled out.

The aim of this paper is to present the results of field observations of spontaneous relations between the Amazon ant $P$. rufescens and F. polyctena, a common wood ant species. These relations included mutual behavioural responses of the heterospecific individuals (and especially their groups) encountering in various situations, as well as socially parasitic relationship between the slave-maker and F. polyctena as a possible atypical host species.

\section{Study area, material and methods}

The investigations were conducted in the Białowieża Forest (NE Poland) near the village of Topiło from 2001 to 2003 from mid-July till midAugust, i.e. within the period of $P$. rufescens raiding activity. Two big colonies of $P$. rufescens, PR-I (found in 2001), nesting inside a rotten stump and in the soil at it, and PR-II (found in 2002), nesting in a low earth bank, were observed practically every day within the study periods when the weather seemed to be good enough for Amazons' raids. Their raiding columns were estimated to comprise up to 2,000 workers. The calculations (very rough estimates) were based on the number of individuals crossing an imaginary line in a unit of time, and the time it took the entire tight column to cross that line.

Both colonies nested within territories of the wood ant $F$. polyctena. PR-I inhabited a neglected coniferous-deciduous forest plantation, nesting in a part of it which was not intensively searched by wood ants coming from a vast multinest polydomous system consisting mainly of small, often unstable stump-side nests; its raids, however, entered the intensively searched part of the habitat (see Czechowski \& Markó 2006 and Fig. 1 in Czechowski 2007). PR-II lay in a dry light spruce-pine forest, within the area intensively searched by $F$. polyctena, at a point where wood ants' routes forked, $7.5 \mathrm{~m}$ away from the nearest fairly big $F$. polyctena nest FP-I $(\varnothing \approx 60$ $\mathrm{cm})$, a member of a well established polydomous colony comprising a few nests. Contacts between the two species were observed in the following situations: (1) everyday encounters of $P$. rufescens (and its $F$. fusca nestmates) with $F$. polyctena in the vicinity of the Amazons' nests, (2) crossings of $F$. polyctena nest-areas or its foraging routes by $P$. rufescens raiding columns, and (3) direct raiding of $P$. rufescens on $F$. polyctena colonies.

\section{Results}

\subsection{Relations in the vicinity of the $P$. rufescens nests}

P. rufescens nest PR-I lay in the zone only sparsely searched by wood ants. However, in 2002 , that nest was 'investigated' by the nearest $(10.2 \mathrm{~m}) \mathrm{F}$. polyctena colony, which nested in a shady, overgrown place and was evidently looking for a new nesting place (establishing small short-lived 'trial' nests here and there). Usually in the afternoons, single $F$. polyctena scouts came right up to nest PR-I, thoroughly searched the area and returned straight to their nest. During the reconnaissance they avoided contact with occasionally encountered Amazon workers and their numerous $F$. fusca slaves; the former paid no attention to these 'scouts' and the latter sometimes harmlessly chased the intruders over a few centimetres (compare to the event described in subsection 3.3).

The mean dynamic density $( \pm$ standard deviation) of dispersed wood ant workers around the other $P$. rufescens nest, PR-II, measured at noon 
ca. $1 \mathrm{~m}$ away from the main nest holes, was $15.5 \pm$ 5.2 inds. $\times 0.25 \mathrm{~m}^{-2} \times 5 \mathrm{~min}^{-1}(\mathrm{n}=6)$. Besides their frequent encounters with enslaved $F$. fusca, which were a matter of course in those circumstances, there were not even the slightest conflicts between them and no aggressive behaviour towards single Amazon ants was recorded. During mass raiding activities of $P$. rufescens (recruitment circling around the nest, marching out and return of raiding columns), dispersed $F$. polyctena usually simply moved aside without protest. Aggressive responses of some $F$. polyctena towards $P$. rufescens were rare. Such aggressive wood ant individuals were generally driven away or sometimes even immediately killed. The only violent conflict noticed close to nest PR-II happened in 2002, when a pre-raid circle of extremely excited Amazon workers, so-called 'activists' according to Dobrzańska's and Dobrzański's (1960) terminology, moved too close to the main $F$. polyctena FP-I foraging route that ran 1 $\mathrm{m}$ from the $P$. rufescens nest entrances. That section of the route was $1.5 \mathrm{~m}$ wide and the mean dynamic density $( \pm \mathrm{SD})$ of wood ants within it was as high as $766 \pm 42$ inds. $\times 0.25 \mathrm{~m}^{-2} \times 5 \mathrm{~min}^{-1}(\mathrm{n}=$ 5 ). Only this route, and only in this (initial) section, was impassable for $P$. rufescens, both single scouts and raiding columns (see below), and normally the Amazons did not try to move in that direction. On the day of the conflict, the outermost $P$. rufescens individuals were fiercely attacked by the wood ants and about a dozen of them - each assailed by tens of infuriated $F$. polyctena workers -were killed with no response from the rest of their swarm (see also Czechowski 2006 and Fig. 2 in Czechowski 2007).

\subsection{Relations on the routes of $P$. rufescens raiding columns}

The event that marked the starting point for observations of the relations between the Amazons and the wood ants was a successful 55-meter raid of $P$. rufescens colony PR-I on a $F$. fusca nest situated within the area intensively searched by $F$. polyctena. Along the way towards their goal (and back) the raiding column passed between two small $F$. polyctena nest situated only $6.5 \mathrm{~m}$ apart (FP-IV and FP-V; see Fig. 4 in Czechowski \&
Markó 2006). The raided nest itself was situated $4.5 \mathrm{~m}$ away from one of those two nests. That Amazons' raid did not provoke any response from nearby colonies of $F$. polyctena or even visible interest on the part of wood ant workers which were densely searching the area. Later both outbound and inbound raiding columns of PR-I were seen many times to pass very close to nests of $F$. polyctena (even less than $0.5 \mathrm{~m}$ from mound edges), again with no or hardly any response of the wood ants. Once a group of about $20 \mathrm{~F}$. polyctena workers coming down the mound attempted to attack an inbound column of $P$. rufescens but their attack was prevented within seconds by a few Amazon ants from the column which launched a counter-strike without letting go of the pupae in their mandibles.

Foraging routes of $F$. polyctena within the raiding distance of colony PR-I were not very distinct. P. rufescens columns would cross them without the slightest difficulty and frightened wood ant foragers would then scatter towards the sides or wait on grass blades for the column to pass.

Raids of colony PR-I on F. fusca co-nesting with $F$. polyctena in one stump (a plesiobiosis frequently observed in this habitat; see Czechowski 2002) took place three times during one season (2002). Even though the closest nest holes of the two plesiobiotic nests were not more than $20 \mathrm{~cm}$ apart, neither the attacking Amazons took interest in the nearby wood ants' nests (or the ants themselves), nor the latter reacted to the conflict taking place in their immediate vicinity. A similar situation was also observed when the $F$. fusca colony raided by $P$. rufescens PR-I formed a plesiobiotic relationship (also in a stump) with Tetramorium caespitum (L.). Again, the close neighbour did not react in any way. On another occasion an Amazon column walked over a soil mound of $T$. caespitum on their way, again without any response of the latter. The raiding columns of $P$. rufescens PR-II also walked unpunished over nests of Lasius niger (L.) and L. platythorax Seifert, and on one occasion these Amazons entered and penetrated a nest of Myrmica sp. without any harm to either party.

P. rufescens colony PR-II nested and operated within a territory much more numerously populated by $F$. polyctena in comparison with 
that settled by PR-I and so PR-II faced much larger wood ant colonies, resulting in more spectacular relations between Amazons and wood ants during such encounters as described above. Colony PR-II also freely raided $F$. fusca near nests of $F$. polyctena and the latter's foraging routes, and PR-II columns would cross wood ants' routes practically unpunished. Thus, a raid on a target nest situated only $1 \mathrm{~m}$ away from a small $(\varnothing=40 \mathrm{~cm})$ but very active $F$. polyctena nest provoked only slight excitement among wood ants. The inbound and outbound route of another raid ran along the edge of a sand bank surrounding the much larger mound of nest FP-I (see above), but the response of its inhabitants was similarly restrained.

Two days before the fierce conflict between $F$. polyctena workers from their foraging route towards $P$. rufescens 'circlers' at nest PR-II described in subsection 3.1., a raiding column crossed the same wood ants' route at a point about $10 \mathrm{~m}$ away from the place of that conflict. The route was $1 \mathrm{~m}$ wide at that point and the mean dynamic density of wood ant workers within it was $165 \pm 17$ inds. $\times 0.25 \mathrm{~m}^{-2} \times 5 \mathrm{~min}^{-1}(\mathrm{n}=5)$. Since the Amazons crossed the route at a sharp angle, the raid and the foraging route overlapped over a distance of about $1.5 \mathrm{~m}$ and wood ants' traffic was only slightly disturbed. No incidents were noticed during the crossing of the Amazon columns (both outbound and inbound) with the wood ants' route. An especially unusual sight was that of $P$. rufescens carrying pupae, walking in loose array "hand in hand" with wood ant foragers carrying their prey. Even single straggling $P$. rufescens entered the column of $F$. polyctena workers without hesitation and were able to get to the other side without difficulty.

In the next season (2003) F. polyctena colony FP-I formed a filial nest approximately $25 \mathrm{~m}$ away from the maternal nest. Throughout the period of observations both nests were connected by a very busy $30-40 \mathrm{~cm}$ wide two-way removal trail, on which wood ants used to carry ceaselessly huge numbers of larvae, pupae and adults (workers and fertile queens) to the new nest. The trail ran $4 \mathrm{~m}$ away from $P$. rufescens nest PR-II. Two raids of Amazon ants collided with that trail. On the first occasion, the outbound column met the removal trail at a right angle. The head of the column, without mishap or even slowing down, entered and crossed a dense trail of wood ants, which parted in front of the former like the biblical Red Sea. That raid turned out to be a failure; one meter behind the trail the head of the column stopped and, after searching unsuccessfully for their target (beyond the $F$. polyctena trail) for a few minutes the Amazons began to go back. The disruption of $F$. polyctena traffic lasted about 10 min. During that time wood ants gathering on both sides of the column captured and killed several (not more than 20) individuals of $P$. rufescens without any response or interest from the part of their nestmates.

The other occasion, several days later, involved a $P$. rufescens outbound column approaching the removal trail of $F$. polyctena at a sharp angle. At the point when it met the trail, the column stopped and the Amazons started to circle looking for their target. The search circle of $P$. rufescens ants spread all across the trail, forcing wood ants aside. The trail was blocked for about 15 minutes until the Amazon ants found their target, a $F$. fusca nest situated a meter away from there. This time, the aggressive response of $F$. polyctena was even weaker, with very few victims (three $P$. rufescens workers were seen to be killed). At the same time some wood ants carrying larvae and pupae sought refuge on herbs to wait for the commotion to end, with the Amazons paying no attention to them just like before.

A totally conflict-free crossing of an Amazon raiding column (both outbound and inbound) was also observed for colony PR-I, which walked across a removal trail (less busy than the one described above) of a $F$. polyctena colony raided(!) a few days earlier (see below).

\subsection{Direct raids of $P$. rufescens on the wood ants' nests}

P. rufescens colony PR-I was the only one to invade nests of $F$. polyctena. A total of eight such attacks were observed in 2001 and 2002, some of them won and some lost, some successful and some failed. The targets were situated $3.3-8.2 \mathrm{~m}$ away from nest PR-I (see Fig. 1 in Czechowski 2007). Most were small unstable colonies of $F$. polyctena, with several hundred ants in each that 
moved from place to place possibly due to overgrowing (shading) of the habitat. These raids of $P$. rufescens on wood ants' nest can be divided into accidental and 'intended' (i.e. originally directed to that very, previously detected, target) on the basis of the circumstances and behaviour of the Amazon ants.

Two of the raids were definitely accidental. On one occasion, in 2001, a column was halfway through (3.3 m away from PR-I) to the $F$. fusca nest when it 'bumped into' a very small (incipient?) $F$. polyctena colony in a clump of grass filled with fine plant nest material. A part of the column attacked the nest while the rest continued their march. Wood ant workers immediately began to flee up plant stems, some carrying pupae (they still had not come down two hours after the raid). No fighting was observed but the smell of formic acid could be felt in the air. The Amazons began to carry away pupae and larvae, gaining a spoil of about 200. When the main column of $P$. rufescens was returning empty-handed from their actual target near (or actually over) the nest being looted, again only a very small part joined in the action and the rest simply continued their march. However, on the next day, $P$. rufescens carried out another raid on the same $F$. polyctena nest, this time deliberate and involving the entire column, and gained several tens more pupae and larvae.

The other accidental raid, in 2002, was against a temporary bivouac of a small $F$. polyctena colony migrating from dense shrubs. The bivouac had been unluckily established on a line connecting nest PR-I (4.1 $\mathrm{m}$ away from it) with a F. fusca nest nearby. When the head of the column encountered the bivouac, wood ant workers with pupae dispersed all around. Some Amazon ants also scattered and returned to their nest while the rest, despite some defensive attempts that lasted a few seconds, took over the bivouac, gaining about 100 pupae. Then $F$. fusca slaves that had been following the Amazon column searched the area for a few hours, collecting abandoned pupae (at least several tens were found) and injured or dead wood ants, including a half-dead $F$. polyctena queen. The Amazons carried out a second raid in the same direction immediately after returning to their nest, but stopped at the site on the (former) bivouac and, after a moment of con- fusion, came back to their nest. It was only during their third attempt that they finally managed to reach the nest of $F$. fusca which was probably their original target.

Of the six raids that could be regarded as intentional attacks on wood ants' colonies, including four successful attempts, the most spectacular raid took place in 2001. The target was a $F$. polyctena nest situated $6 \mathrm{~m}$ away from PR-I. The mound had a diameter of $20 \mathrm{~cm}$ and was $8 \mathrm{~cm}$ high. The moment the Amazons launched an attack, queens (three were seen) and workers with pupae began to flee the nest immediately. Some climbed on nearby plants but most of them dispersed in all directions. The nest was attacked directly by a relatively small part of the Amazon forces, but this group of attackers was still numerous enough to cover the surface of the mound completely. The remaining Amazons surrounded the nest, forming a dense ring of $0.5 \mathrm{~m}$ width. The Amazon ants forming the cordon were extremely excited, paying no attention to $F$. polyctena workers with pupae that were trying to break through the cordon to get away from the danger zone (this is a characteristic behaviour of $P$. rufescens, observed also when it is confronting its typical host species; Dobrzańska \& Dobrzański 1988). Only after all wood ants had left the nest did the surrounding Amazons enter it to carry away several hundred pupae and larvae that were left there. As soon as P. rufescens workers formed the home-bound column when leaving the attacked nest, $F$. polyctena that were dispersed around the nest returned to it in massive numbers. Now they covered the surface of the mound densely and attacked Amazon stragglers leaving the nest with their spoils. Victims were few: not more than a dozen or so $F$. polyctena workers killed at the moment of attack and an equal number of $P$. rufescens stragglers. At least one dealate gyne of $P$. rufescens took part in the raid, but it returned to the maternal nest with the inbound column.

$F$. fusca slaves also took part in that raid of $P$. rufescens on $F$. polyctena. They followed the Amazon column to the site of the attack, mingling with some of its rear, less numerous segment. They did not attack the $F$. polyctena nest, but went on to collect pupae dropped by the fleeing wood ants. Later, when all P. rufescens had left 
the site, $F$. fusca searched for pupae hidden in the grass for a few more hours. Notably, enslaved $F$. fusca workers would never do this during raids on nests of their conspecifics, but those targets were usually situated much farther away (up to $55 \mathrm{~m}$ in the case of PR-I) from the P. rufescens nest (excluding special integration raids; see Czechowski 2005).

Two of the raids on the wood ants met defeat. In one case, in 2001, only the final part was observed: the $P$. rufescens column was retreating, there was a distinct smell of formic acid in the air, and on the $F$. polyctena mound wood ants were killing a few captured Amazons. A later defeated raid in 2002 was followed from the beginning to the end. The target was not, as usual, a very small migrating colony but a new trial nest of a larger colony of $F$. polyctena $(>1,000$ individuals $)$ - the one whose 'scouts' had explored and would later explore $P$. rufescens nest PR-I (see subsection 3.1). The trial nest, situated under a log, was $8.2 \mathrm{~m}$ away from PR-I. It was raided by one of two columns that the original outbound column had split into a few meters away from PR-I. The raiding arm consisted of no more than 1,000 workers. The attack was very violent and so was the ensuing defence and counter-attack of the wood ants. Following a few minutes of fighting all the Amazon forces began to flee at the same moment, running away in panic in all directions. After a while most began to retreat to their nest in disarray, but tens of scattered Amazons were still wandering around the area or could be found high up on blades of grasses and herbs a few hours later. Several dozen were killed on the $F$. polyctena nest in the first phase of the conflict. Three days later $P$. rufescens raided the same target, this time using all its forces, only to find the trial nest completely abandoned; after the first attack the $F$. polyctena colony had returned to its own permanent nest.

Both in 2001 and 2002 colony PR-I of $P$. rufescens gained at least 200-300 worker pupae and last instar larvae of $F$. polyctena (that was the number observed but raiding periods of Amazon ants lasted longer than the observations). However, no enslaved wood ant workers were found ever in PR-I later. As a footnote, it should be mentioned that in 2002 an experiment was carried out where a pile of worker pupae of Formica (Coptoformica) exsecta Nyl. and F. sanguinea, the latter with its enslaved pupae of $F$. (Serviformica) cinerea Mayr and $F$. fusca, a total of about 3,000 individuals were put out $2 \mathrm{~m}$ away from nest PR-II. F. fusca slaves immediately started to pick them up, assisted by massive numbers of $P$. rufescens workers forming a very busy two-way route between their nest and the pupae pile. Next year, however, no slaves other than $F$. fusca were found in colony PR-II.

\section{Discussion}

The observed encounters between $F$. polyctena and $P$. rufescens in the field were usually characterized by mutual indifference of these ant species. On most occasions, the response of wood ants to the presence of Amazon ants, if there was any, could perhaps best be described as the former being 'intrigued' by the unusual situation or abnormally high concentration of strangers rather than assuming an aggressive attitude. $F$. polyctena would only display aggression (usually quickly turning into panic) when facing a direct attack of $P$. rufescens on its nests, but in such situations aggressive behaviour is obvious. The only occasion when $F$. polyctena displayed overt aggression towards $P$. rufescens outside their own nest was when wood ants from a foraging route attacked 'careless' Amazon 'circlers' which had come too close to the route (see Czechowski 2006). It appears that this aggression should be associated with enormous (pheromone-induced) agitation of Amazon workers in that particular pre-raid phase, comparable to the level of agitation while attacking their target nest. This is also related to the fact that only the part of the $F$. polyctena foraging route, adjoining the $P$. rufescens recruitment arena, was impassable for the Amazon ants. This is a good illustration of a point made long ago by J. Dobrzańska and J. Dobrzański, who wrote that "ants are able to distinguish a passive attitude from a combative attitude of other species, and their response actually depends on the behaviour of the latter" (Dobrzańska \& Dobrzański 1962, Dobrzańska 1976).

A particularly spectacular aspect of the interspecific relations described in this paper was that Amazons' raiding columns were able to freely cross, almost without losses, the dense and wide 
routes of wood ants. It was very surprising, especially in the light of previous reports of the entire $P$. rufescens colony dying out under similar conditions (Dobrzański \& Dobrzańska 1978 and Dobrzańska \& Dobrzański 1989; unfortunately these authors provide no information on the traffic intensity on the $F$. rufa route crossed by $P$. rufescens or on the size of the $F$. rufa colony). It is possible that the distinctly different attitudes of wood ants towards $P$. rufescens in apparently the same situation were motivated by the presence of different slave species in those Amazon colonies, a consequence of which were their different colony labels. Despite some uncertainties in this regard (see Liu et al. 2003), slave-maker ants become olfactorily similar to the slave species present in the colony. In Polyergus species this is achieved through chemical camouflage (Yamaoka 1990) or chemical mimicry (e.g. Habersetzer \& Bonavita-Cougourdan 1993, Bonavita-Cougourdan et al. 1996, 1997, D'Ettore \& Heinze 2001). Thus, slave-makers which co-exist with different slave species can be perceived variously by other ants, including both their hetero- and conspecifics. The above hypothesis is supported, for example, by enormous intraspecific aggressiveness in $F$. sanguinea when a confronted party includes a large proportion of $F$. polyctena slaves (Czechowski 1994). If this assumption is true, then the attitude of $F$. polyctena towards $P$. rufescens should generally resemble its attitude towards free living ants of a given slave species, which is, in turn, related to the position of the latter in interspecific competition dominance hierarchy (see Savolainen \& Vepsäläinen 1988, Pisarski \& Vepsäläinen 1989).

Like all wood ants, $F$. polyctena is a typical territorial species, the frequent top dominant of forest ant assemblages (Savolainen \& Vepsäläinen 1988, 1989, Savolainen et al. 1989). The papers of Dobrzański \& Dobrzańska (1978) and Dobrzańska and Dobrzański (1989) that describe the destruction of a $P$. rufescens colony by wood ants do not mention its slave species. Other studies by the same authors indicate that 'their' $P$. rufescens enslaved $F$. cinerea and $F$. rufibarbis $\mathrm{F}$. as well as $F$. fusca. It is now known that the name $F$. rufibarbis could also refer to $F$. lusatica Seifert (see Seifert 1997) (=F. glauca Ruzs. sensu Seifert 1996 and Czechowski et al. 2002b). Formica cinerea, $F$. rufibarbis and $F$. lusatica, unlike $F$. fusca (and $F$. cunicularia Latr., another frequent slave species), can be very aggressive towards other ant species, both in socially parasitic and competitive relations. They are known for their fierce (and often effective) defence of their nests against slave-makers (Dobrzańska 1978a, Dobrzańska \& Dobrzański 1989, Grasso et al. 1994, Le Moli et al. 1994b, Mori et al. 1994, Czechowski \& Rotkiewicz 1997, Seifert 1997, D’Ettore et al. 2004, Czechowski \& Radchenko 2006, A. Mori, pers. comm., W. Czechowski, unpubl.).

Formica cinerea, in respect of its status in interspecific competition hierarchy, is potentially a territorial species (Markó \& Czechowski 2004), able to successfully compete for territory against wood ants (Dlussky 1967, Czechowski \& Markó 2005 and unpubl.). Big colonies of the two remaining aggressive Serviformica species, especially those of $F$. lusatica, are also supposed to be potentially territorial (Seifert 1996). Interspecific competition hierarchy assumes that nesting of one territorial species on the territory of another territorial species is not possible, and the occurrence of intruders invariably ignites a conflict. At the same time, F. fusca is a non-aggressive, nonterritorial, subordinate submissive species which represents the lowest level in interspecific dominance hierarchy. An individualistic and opportunistic manner of foraging and evasive behaviour enables $F$. fusca not only to nest fairly close to wood ant colonies but also to search freely (though not without limitations) right next to their mounds (see Savolainen 1990, 1991). According to the hypothesis proposed above, $F$. polyctena could have perceived Amazons nesting within their territories or crossing through as $F$. fuscalike ants that have 'a natural right' to stay there. Further studies are needed to clarify the proposed mechanism.

During a conflict Amazons are never the first to start individual physical combats; they react, using their mandibles and, rarely, formic acid, only when they have been attacked themselves (e.g. Czechowski 1975b, Mori et al. 2001). Helping a nestmate whose life is in danger is also not characteristic of this species (Czechowski 1977, 2003a) (unlike $F$. sanguinea; see e.g. Czechowski et al. 2002a). This strategy allows them to minimize their own losses during interspecific 
conflicts, very spectacular examples of which could be observed during their encounters with foraging routes of $F$. polyctena, when there was direct contact between dense columns of two potentially very aggressive ant species. The immediate retreat of an entire column, when the opponent is overwhelmingly strong, as is often the case if the opponent is a wood ant colony, should also be considered an element of this strategy, as well as a sign of some behavioural plasticity of Amazon ants. Dobrzańska (1978b) was the first to regard the escape reaction as an atavistic sign of plasticity of $P$. rufescens in the context of its 'functional degeneration'.

Old myrmecological literature contains some information of socially parasitic relations between $P$. rufescens and Formica s. str. species. However, these are descriptions of experimental, sometimes successful, attempts to force wood ant workers to adopt a queen of $P$. rufescens (see e.g. Regnier 1930). Evidence for spontaneous adoption of this kind in the field is lacking (which does not mean that it is impossible). Forel's (1900) report, cited in the Introduction, of a natural mixed colony of $F$. pratensis/F. fusca/P. rufescens containing $F$. pratensis queens, actually indicates the opposite: the taking over of a (queenless?) Amazon colony by queen(s) of $F$. pratensis, as it happens in the relations of the latter with $F$. sanguinea (Czechowski 2001). For the possibility of mutual temporary social parasitism of Formica s. str. species and $F$. sanguinea see Czechowski (2003b).

The present paper provides the first direct evidence of the very dulotic relations between $P$. rufescens and the wood ants, although they involved only nest raiding and robbery of $F$. polyctena pupae; non-typical slaves, in all probability, did not emerge. However, that does not mean that wood ant workers cannot be used as slaves by $P$. rufescens. Most probably, it is $F$. fusca slaves already present in the colony that are to 'blame' for killing wood ant workers in the bud.

In slave-maker ant colonies, including those of Amazons, many of the pupae retrieved by the raiders are consumed (Dobrzański 1965, Czechowski 1975a, Cool-Kwait \& Topoff 1984). Since Polyergus individuals are fed by their slaves, it is slaves who consume the captured brood, which is also a selection procedure. It has been demonstrated that slaves in P. lucidus Mayr destroy a greater proportion of heterospecific than of homospecific slave pupae (Goodloe \& Topoff 1987). J. Dobrzański (unpubl.) came to the same conclusion earlier on the basis of his own observations of a $P$. rufescens colony. Still, Amazon colonies, at least in P. rufescens, containing slaves of more than one species do occur in nature, though rarely (Dobrzańska \& Dobrzański 1960, Dobrzańska 1976, Czechowski 1975a). This is much more common in $F$. sanguinea colonies (including wood ants as slaves; e.g. Czechowski 1989), but the proportion of slaves is incomparably smaller there (for review see Czechowski 1996) than in Amazons' colonies, where it reaches 80-90\% (Seifert 1996).

Besides raiding wood ant nests, another interesting aspect of the biology of mixed colonies of P. rufescens (and of Amazon ants in general) and their slaves observed in the present study was a certain participation of slaves in some such raids. $P$. rufescens' slaves do not accompany their keepers in their raids as a rule (Mori et al. 1991, Le Moli et al. 1994a), this being unlike the behaviour of blood red ants' slaves of different species (F. fusca, F. cinerea, F. cunicularia), which may happen to take part, sometimes very actively, in raids (Czechowski 1998 and unpubl., Mori et al. 2000, Mori et al. 2001). Forms of co-operation between slaves and $P$. rufescens workers during raiding activity of the latter known from previously published papers (Dobrzańska 1976, 1978a) included $F$. fusca slaves widening nest holes for the inbound column carrying their spoils or F. cinerea slaves taking over pupae from Amazons on the 'outskirts' of the nest.

However, the instances of co-operation described in this paper should not be interpreted as a contribution of slaves to the raiding activity of their slave makers, but rather as organized activity of $F$. fusca workers themselves causally and in terms of time related to actions undertaken by $P$. rufescens. The departure of a raiding column always causes agitation among slaves. They emerge on the surface in greater numbers and are very excited, with some running a few metres within and behind the column (Czechowski 1975b, Dobrzańska 1976, 1978a). Reported raids of $P$. rufescens on $F$. polyctena were over very 
short distances so that some $F$. fusca workers could easily run as far as the target nest and find scattered alien pupae. In these situations, F. fusca promptly starts collecting the pupae (=food items), enrolling the help of more nestmates from the nest. Such raiding-like, or actually foraging, activity can be easily elicited in free-living $F$. fusca colonies (W. Czechowski, unpubl.). Nevertheless, the fact remains that such behaviour of slaves, irrespective of its origin and mechanism, was an effective complementary action assisting the activity of $P$. rufescens workers as the latter do not pick up abandoned pupae found around raided nests (Dobrzańska \& Dobrzański 1988).

Acknowledgements. This paper is dedicated to Assist. Prof. Dr. Jan Dobrzański, a Polish ethologist and myrmecologist, an eminent researcher of the slavery in ants, whose $85^{\text {th }}$ birthday falls in 2007 . The author wishes to thank three unknown reviewers, whose questions, doubts and suggestions helped to improve the original version of the manuscript. The ms benefited greatly also from an additional polite review by Bálint Markó. The field study was financially supported by the Museum and Institute of Zoology PAS, Warsaw.

\section{References}

Bonavita-Cougourdan, A., Bagnères, A.-G., Provost, E., Dusticier, G. \& Clèment, J.-L. 1997: Plasticity of the cuticular hydrocarbon profile of the slave-making ant Polyergus rufescens depending on the social environment. - Comp. Biochem. Physiol. B 116: 287-302.

Bonavita-Cougourdan, A., Rivière, G., Provost, E., Bagnères, A.-G., Roux, M., Dusticier, G. \& Clèment, J.-L. 1996: Selective adaptation of the cuticular hydrocarbon profiles of the slave-making ants Polyergus rufescens Latr. and their Formica rufibarbis Fab. and F. cunicularia Latr. slaves. - Comp. Biochem. Physiol. B 113: 313-329.

Cool-Kwait, E. \& Topoff, H. 1984: Raid organization and behavioral development in the slave-making ant Polyergus lucidus Mayr. - Insect. Soc. 31:361-374.

Czechowski, W. 1975a: Mixed polycalic colony of Formica (Serviformica) cinerea Mayr and Polyergus rufescens Latr. (Hymenoptera, Formicidae). — Ann. Zool. (Warsaw) 33: 67-75.

Czechowski, W. 1975b: Slave-raids of the ant Polyergus rufescens Latr. (Hymenoptera: Formicidae). Przegl. Zool. 19: 449-463. [In Polish].

Czechowski, W. 1977: Recruitment signals and raids in slave-maker ants. - Ann. Zool. (Warsaw) 34: 1-26.

Czechowski, W. 1989: Functioning of a mixed colony of Formica sanguinea Latr. $+F$. polyctena Foerst. (Hymenoptera, Formicidae) with a surplus of slaves. -
Ann. Zool. (Warsaw) 43: 103-126.

Czechowski, W. 1994: Impact of atypical slaves on intraspecific relations in Formica sanguinea Latr. (Hymenoptera, Formicidae). - Bull. Acad. Pol. Sci., Biol. Sci. 42: 345-350.

Czechowski, W. 1996: Colonies of hybrids and mixed colonies; interspecific nest takeover in wood ants (Hymenoptera, Formicidae). - Memorabilia Zool. 50, $116+$ $\mathrm{xx}$ pp.

Czechowski, W. 1998: Raids of Formica sanguinea Latr. as a factor conducive to colony founding by Formica truncorum Fabr. (Hymenoptera, Formicidae). Ann.Upper Siles. Mus., Entomol. (Bytom) 8/9: 153157.

Czechowski, W. 2000: Interference of territorial ant species in the course of raids of Formica sanguinea Latr. (Hymenoptera, Formicidae). - Ann. Zool. (Warsaw) 50: $35-38$.

Czechowski, W. 2001: Mixed colony of Formica pratensis Retz. + Formica cinerea Mayr + Formica sanguinea Latr. (Hymenoptera, Formicidae) and its presumed origin. - Ann. Zool. (Warsaw) 51: 205-209.

Czechowski, W. 2002: Plesiobiosis between Formica fusca L. and wood ants (Hymenoptera, Formicidae) as a sign of nest competition. - Przegl. Zool. 46: 81-86. [In Polish].

Czechowski, W. 2003a: Polyergus rufescens (Latr.) (Hymenoptera, Formicidae) and an ant lion - an ethological observation and its evolutionary background. Przegl. Zool. 47: 109-113. [In Polish].

Czechowski, W. 2003b: Wood ants and Formica sanguinea Latr. (Hymenoptera, Formicidae) - a case of mutual social parasitism. - Przegl. Zool. 47: 149160. [In Polish].

Czechowski, W. 2005: Integration raids in the Amazon ant Polyergus rufescens (Hymenoptera, Formicidae). Insect. Soc. 52: 103-104.

Czechowski, W. 2006: The route of Formica polyctena Först. as a factor promoting emancipation of Formica fusca L. slaves from colonies of Polyergus rufescens (Latr.) (Hymenoptera: Formicidae). — Pol. J. Ecol. 54: $159-162$.

Czechowski, W. 2007: Do Polyergus rufescens (Latr.) and Formica sanguinea Latr. (Hymenoptera: Formicidae) share resources of slave species with each other? Pol. J. Ecol. 55. (In press).

Czechowski, W., Godzińska, E. J. \& Kozłowski, M. W. 2002a: Rescue behaviour shown by workers of Formica sanguinea Latr., F. fusca L. and F. cinerea Mayr (Hymenoptera: Formicidae) in response to their nestmates caught by an ant lion larva. - Ann. Zool. (Warsaw) 52: 423-431.

Czechowski, W. \& Markó, B. 2005: Competition between Formica cinerea Mayr (Hymenoptera: Formicidae) and co-occurring ant species, with special reference to Formica rufa L.: direct and indirect interferences. Pol. J. Ecol. 53: 467-489.

Czechowski, W. \& Markó, B. 2006: Uncomfortable protection: Formica polyctena Först. defends Formica fusca L. against Formica sanguinea Latr. (Hyme- 
noptera: Formicidae). -Ann. Zool. (Warsaw) 56: 539-548.

Czechowski, W. \& Radchenko, A. 2006: Formica lusatica Seifert, 1997 (Hymenoptera: Formicidae), an ant species new to Finland, with notes on its biology and the description of males. - Myrm. Nachr. 8: 257-262.

Czechowski, W., Radchenko, A. \& Czechowska, W. 2002b: The ants (Hymenoptera, Formicidae) of Poland. - Museum and Institute of Zoology PAS, Warsaw. 200 pp.

Czechowski, W. \& Rotkiewicz, W. 1997: Relations between Formica sanguinea Latr. and Formica cinerea cinerea Mayr (Hymenoptera, Formicidae) - an unusual form of dulosis. - Ann. Zool. (Warsaw) 47: 469-478.

Czechowski, W. \& Vepsäläinen, K. 2001: Formica rufa L. protects indirectly $F$. fusca L. against raids of $F$. sanguinea Latr. (Hymenoptera: Formicidae). — Ann. Zool. (Warsaw) 51: 267-273.

Dekoninck, W., Versteirt, V. \& Grootaert, P. 2001: Rediscovery of a colony Polyergus rufescens (Latreille, 1798 ) in Belgium: observations at the "Hageven" Nature reserve (Hymenoptera Formicidae). - Bull. Soc. Royale Belge Entomol. 137: 98-101.

D'Ettore P. \& Heinze, J. 2001: Sociobiology of slave-making ants. - Acta Ethol. 3: 67-82.

D’Ettore, P., Brunne, E., Wenseleers, T. \& Heinze. 2004: Knowing your enemies: seasonal dynamics of hostsocial parasite recognition. - Naturwissenschaften 91: 594-597.

Dlussky, G. M. 1967: [Ants of the genus Formica (Hymenoptera, Formicidae)]. Nauka, Moskva. 236 pp. [In Russian].

Dobrzańska, J. 1976: (Studies on social parasitism in ants from the point of view of interspecific adaptative behaviour). - Kosmos A 25: 223-242. [In Polish].

Dobrzańska, J. 1978a: Problem of behavioral plasticity in slave-making Amazon-ant Polyergus rufescens Latr. and its slave-ants Formica fusca L. and Formica cinerea Mayr. -Acta Neurobiol. Exp. (Warsaw) 38: $113-132$.

Dobrzańska, J. 1978b: Evaluation of functional degeneration of the Amazon-ant Polyergus rufescens Latr. under an influence of socially parasitic way of life. Acta Neurobiol. Exp. (Warsaw) 38: 133-138.

Dobrzańska, J. \& Dobrzański, J. 1960: Quelques nouvelles remarques sur l'éthologie de Polyergus rufescens Latr. (Hymenoptère, Formicidae). - Insect. Soc. 7: $1-8$.

Dobrzańska, J. \& Dobrzański, J. 1962: Quelques observations sur les luttes entre différentes espèce fourmis. Acta Biol. Exp. (Warsaw) 22: 269-277

Dobrzańska, J. \& Dobrzański, J. 1988: (Social parasitism in ants. Obligatory parasitism). — Kosmos 37: 617639. [In Polish].

Dobrzańska, J. \& Dobrzański, J. 1989: Controversies on the subject of slave-raids in Amazon ants (genus Polyergus). - Acta Neurobiol. Exp. (Warsaw) 49: 367-379.

Dobrzański, J. 1965: Genesis of social parasitism among ants. - Acta Biol. Exp. (Warsaw) 25: 59-71.

Dobrzański, J. \& Dobrzańska, J. 1978: Some questions related to mechanisms of slave-raids in amazon-ant Polyergus rufescens Latr. - Acta Neurobiol. Exp. (Warsaw) 38: 353-359.

Forel, A., 1900: Fourmilière triple naturelle. — Mitt. Schweiz. Entomol. Ges. 10: 280-282.

Goodloe, L. P. \& Topoff, H. 1987: Pupa acceptance by slaves of the socially parasitic ant Polyergus. - Psyche 94: 293-302.

Grasso, D. A., Mori, A., D’Ettore, P. \& Le Moli, F. 1994: Intraspecific raids and territoriality in Polyergus rufescens Latr. (Hymenoptera Formicidae). — Ethol. Ecol. Evol., Special Issue 3: 81-87.

Habersetzer, C. \& Bonavita-Cougourdan, A. 1993: Cuticular spectra in the slave-making ant Polyergus rufescens and the slave species Formica rufibarbis. - Physiol. Entomol. 18: 160-166.

Le Moli, F., Grasso, D. A., Mori, A. \& Ugolini, A. 1994a: Eco-ethological factors affecting the scouting and raiding behaviour of the slave-making ant, Polyergus rufescens Latr. (Hymenoptera, Formicidae). — Ethology 96: 289-302.

Le Moli, F., Mori, A. \& Grasso, D. A. 1994b: Behavioural ecology of the obligatory slave-making ant, Polyergus rufescens Latr. (Hymenoptera, Formicidae). A review. - Memorabilia Zool. 48: 133-146.

Liu, Z., Bagnères, A.-G., Yamane, S., Wang, Q. \& Kojima, J. 2003: Cuticular hydrocarbons in workers of the slave-making ant Polyergus samurai and its slave, Formica japonica (Hymenoptera: Formicidae). Entomol. Sci. 6: 125-133.

Mabelis, B., 2000: Amazonemier (Polyergus rufescens) duikt op in de Achterhoek (Hymenoptera: Formicidae). - Entomol. Berichten (Amst.) 60: 50-52 [In Dutch].

Markó, B. \& Czechowski, W. 2004: Lasius psammophilus Seifert and Formica cinerea Mayr (Hymenoptera: Formicidae) on sand dunes: conflicts and coexistence. - Ann. Zool. (Warsaw) 54: 365-378.

Mori, A., Grasso, D. A. \& Le Moli, F. 1991: Eco-ethological study on raiding behaviour of the European amazon ant, Polyergus rufescens Latr. (Hymenoptera: Formicidae). - Ethology 88: 46-62.

Mori, A., Grasso, D. A., D'Ettore, P. \& Le Moli, F. 1994: Specificity in host choice by the slave-making ant Polyergus rufescens Latr. (Hymenoptera Formicidae). — Ethol. Ecol. Evol., Special Issue 3: 89-93.

Mori, A., Grasso, D. A. \& Le Moli, F. 2000: Raiding and foraging behavior of the blood-red ant, Formica sanguinea Latr. (Hymenoptera, Formicidae). - J. Insect Behav. 13: 421-438.

Mori, A, Grasso, D. A., Visicchio, R. \& Le Moli, F. 2001: Comparison of reproductive strategies and raiding behaviour in facultative and obligatory slave-making ants: the case of Formica sanguinea and Polyergus rufescens. - Insect. Soc. 48: 302-314.

Pisarski, B. \& Vepsäläinen, K. 1989: Competition hierarchies in ant communities (Hymenoptera, Formicidae). - Ann. Zool. (Warsaw) 42: 321-329. 
Punttila, P., Haila, Y. \& Tukia H. 1996: Ant communities in taiga clearcuts: habitat effects and species interactions. - Ecography 19: 16-28.

Regnier, A. 1930: Un cas typique d'adoption: Polyergus queen and rufa workers. - Biol. Zentr. 50: 25-31.

Savolainen, R., 1990: Colony success of the submissive ant Formica fusca within territories of the dominant Formica polyctena. - Ecol. Entomol. 15: 79-85.

Savolainen, R. 1991: Interference by wood ant influences size selection and retrieval rate of prey by Formica fusca. - Beh. Ecol. Sociobiol. 28: 1-7.

Savolainen, R. \& Vepsäläinen, K. 1988: A competition hierarchy among boreal ants: impact on resource partitioning and community structure. - Oikos 51: 135155.
Savolainen, R. \& Vepsäläinen, K. 1989: Niche differentiation of ant species within territories of the wood ant Formica polyctena. - Oikos 56: 3-16.

Savolainen, R., Vepsäläinen, K. \& Wuorenrinne, H. 1989: Ant assemblages in the taiga biome: testing the role of territorial wood ants. - Oecologia 81: 481-486.

Seifert, B. 1996: Ameisen: beobachten, bestimmen. Naturbuch-Verlag, Augsburg, 352 pp.

Seifert, B. 1997: Formica lusatica n. sp. - a sympatric sibling species of Formica cunicularia and Formica rufibarbis (Hymenoptera, Formicidae). - Abh. Ber. Naturkundemus. Görlitz 69: 3-16.

Yamaoka, R. 1990: Chemical approach to understanding interactions among organisms. - Physiol. Ecol. Jpn. 27: $31-52$. 